\title{
Prevalence of selected viral infections in various age groups of village chickens in Borno State, Nigeria
}

\author{
A.D. El-Yuguda and S. S. Baba \\ Virology Laboratory Department of Veterinary Microbiology and Parasitology, University of \\ Maiduguri, P.M.B. 1069, Maiduguri, Nigeria
}

\begin{abstract}
A preliminary survey for antibodies against some selected viruses in village chickens of various age groups was carried out in Borno State, Nigeria. Three hundred and twenty samples consisting of I60 sera from adult chickens, 60 sera from chicks and 100 yolk samples from embryonated chicken eggs were tested against Newcastle disease (ND), influenza (FLU) A and B viruses, and egg drop syndrome (EDS) - 76 viruses using haemagghtination inhibition (HI) test; and infectious bursal disease (IBD) virus using the agar gel diffusion test (AGDT). Eighty-five percent of the samples tested positive to one or more viruses, with IBD having the highest percentage prevalence (45.7\%) followed by FLU A (26.5\%), ND (22.4\%), EDS-76 (19.3\%) and FLU B (0\%). The percentage of mixed infectious among different age groups was highest among chicks. The importance of village chickens in the spread and maintenance of viral diseases of poultry are discussed from epidemiological point of view.
\end{abstract}

Keywords: Viral antibodies, village chickens, Nigeria

\section{Introduction}

Nigeria has the largest poultry population in Africa (Nawathe and Abegunde, 1980). It has been estimated that the country has about 130 million to 150 million chickens (Abdu et al., 1985; Okoye et al., 1992; Lamorde, 1996). Of these only about $10 \%$ are of the exotic breed (Nawathe and Abegunde, 1980). Village chickens accounts for the remaining population (Abdu, et al., 1985; Jagne, et al., 1991). The village poultry plays an important role in providing proteins and income to the farmers with little or no capital investment (Aini et al., 1987; Ibrahim et al., 1987; Okoye et al., 1992). However, the growth of poultry industry in Nigeria has been hampered by the incidence of 245 infectious diseases (Nawathe and Abegunde, 1980; Elssa, 1985; Danvivatanaporn, 1987; Ibrahim, et al., 1987; Baba et. al., 1998) against which vaccination of the village chicken is rarely practiced (Jagne et al., 1991). The economic impacts of these infectious diseases are much felt in countries located in the hot climatic zones due to the diversity of disease conditions which are often exacerbated by low hygienic conditions (Elssa, 1985) and the lack of vaccination practices (Jagne et al., 1991). The village poultry could play an important role in the transmission of these diseases to commercial poultry (Elssa, 1985; Spradbrow, 1987). 


\section{Yuguda and Baba}

This study attempts to determine the serological evidence of infections by selected viruses among the village chickens in Borno State, Nigeria.

\section{Materials and methods}

\section{Collection of samples}

Three hundred and twenty samples consisting of 160 and 60 serum samples from unvaccinated adult village chickens and chicks respectively and 100 egg yolk samples from embryonated chicken eggs were obtained from various locations in Borno State. The birds were bled through the wing vein using sterile syringe and needle into vaccutainer tubes. The sera were separated by centrifugation at $1,500 \mathrm{rpm}$ for 10 minutes in a mechanical centrifuge while yolk samples were obtained from embryonated chicken eggs. All samples were stored in sterile knuck tubes at $-20^{\circ} \mathrm{C}$ until tested.

\section{Antigens}

Newcastle disease (ND) "Lasota" vaccine batch number 1/97, embryonated egg adapted egg drop syndrome (EDS-76) virus and infectious bursal disease (IBD) virus and their positive control sera were all obtained from the National Veterinary Research Institute (NVRI), Vom, Nigeria. The influenza (FLU) A and $B$ antigens were supplied by the WHO collaborating center for influenza, center for disease control (CDC) Atlanta, Georgia.

\section{Haemagglutination inhibition (Hl) test}

The HI tests for NDV and EDS-76 viruses were carried out as described by Allan and Gough (1974), and for the FLU A and B viruses as described by WHO (1988) protocol for influenza Hi test. Test sera and yolk samples were diluted $1: 10$, heat inactivated at $56^{\circ} \mathrm{C}$ for 30 minutes and tested in two fold serial dilutions against $8 \mathrm{HA}$ units of each of the antigens.
Agar gel diffusion test (AGDT)

The test sera and yolk samples were tested for the presence of antibodies against IBD virus according to standard procedure for the AGDT as described by Hiral et al., (1972).

\section{Results}

Of the 300 samples tested, $254(84 \%)$ reacted with one or more virus antigens (Table 1). These include $82(82 \%)$ of the 100 yolks from ECE, $56(94 \%)$ of 60 sera from chicks and 116 $(83 \%)$ of the 140 sera from chickens. There was no significant difference $(P>0.05)$ in the overall antibody prevalence to the different antigens used among the various age groups of chicken (Table 1). Analysis of the prevalence of antibodies to individual viruses and the levels of mixed infections revealed that antibodies to IBDV was the highest (24\%) (Table 2). In addition, considerable percentage $(27 \%)$ of positive sera reacted with more than one virus antigen (Table 2). With the exception of egg yolks whose antibody titre did not exceed 1:40, majority of the positive sera reacted to high titres 1:40 (Table 3 ).

\section{Discussion}

The results of this survey revealed extensive prevalence of antibodies to some selected viruses among village chickens of different age groups in Borno State, Nigeria. The antibodies detected in this study are likely to be as a result of infections since vaccination of the village poultry is rarely undertaken in Nigeria (Abdu $e t$ al. 1987, Dipeolu et al., 1998). Viral antibodies detected in yolks were slightiy lower in prevalence than those detected in the adult chickens (Table 1). The results of the antibody survey against NDV and EDS-76 virus found in this study, are similar to the findings of Nawathe and Abegunde (1980); Durojaiye and Adene (1988) and Baba et al, (1998), who reported high antibody titres against EDS -76 virus in commercial chickens and EDS-76 virus 


\section{Viral infections of village chickens}

and ND in guinea fowls and village chickens. The high sero prevalence of IBDV found in this study (Table 1) compares with the findings of Akoma and Baba (1995) who reported high activity of the IBDV among free range and commercial birds in Borno State. Similar findings were also reported in guinea fowls by Jong et al. (1992) also reported IBDV as the commonest poultry disease in Kaduna State. Our finding have also shown that the IBDV is the commonest among the 5 viruses investigated in all the age groups of village chickens (Table 1). The results of the antibody prevalence against FLU A and B viruses conform with the findings of Adeniji et al. (1993) who reported the prevalence of antibodies to FLU A virus, but non against FLU B virus among chickens at Ibadan, Nigeria.

The results of this survey have provided significant data on the epidemiology of these viral infections in this environment that would assist in the design of control measures against these infections among village poultry populations. The relatively poor performance of the village chickens in Nigeria could be partly attributed to the multiple and sub clinical infections with these viruses at various level of their developments. The high sero prevalence of IBDV among the village chickens in this study could be associated with the immunosuppressive effects of the IBDV in infected chickens, allowing for secondary opportunities infections by other viruses (Pejkovski et. al., 1979; Abdu et al., 1986; Abdu, et. al., 1987). The village chickens are likely to be the reservoirs of most of these viruses and could play a significant role in their spread to the more susceptible younger birds and commercial poultry (Abdu et. al., 1985).

Considering the epidemiology and health significance of these viral diseases to the poultry industry and humans as well as livestock productions in this country, (Olaleye et al., 1989; Akoma and Baba, 1995), there is the need to introduce appropriate control measures against these virus infections especially among the village chickens to prevent spread to other animals and humans.

Table 1 Prevalence of antibodies to selected vimis in different age groups of village chickens in Borno State, Nigeria

\begin{tabular}{llllllll} 
& & & & \multicolumn{3}{c}{ Number (\%) positive } \\
Age group & Total No. tested & \% positive & ND & IBD & FLU A & FLU B & EDS 76 \\
\hline ECE & 100 & 82 & 32 & 38 & 13 & - & 4 \\
& & $(82)$ & $(10.7)$ & $(12.73)$ & $(4.3)$ & $(1.3)$ \\
Chicks & 60 & 56 & 14 & 29 & 26 & - & 33 \\
& & $(94)$ & $(4.7)$ & $(9.7)$ & $(8.3)$ & - & $(11)$ \\
Adult & \multirow{2}{*}{140} & 116 & 21 & 70 & 43 & - & 21 \\
Chicken & & $(83)$ & $(7)$ & $(23.3)$ & $(14.3)$ & $(7)$ \\
Total & \multirow{2}{*}{300} & $254(85)$ & 67 & 137 & 82 & - & 57 \\
& & $(85)$ & $(22.4)$ & $(45.7)$ & $(26.5)$ & & $(19.3)$ \\
\hline
\end{tabular}




\section{Yuguda and Baba}

- Table 2 Pattern of mixed infections with viruses among village chickens in Borno State, Nigeria

\begin{tabular}{|c|c|c|c|c|c|c|c|c|c|}
\hline \multirow[b]{2}{*}{$\begin{array}{l}\text { Age } \\
\text { group }\end{array}$} & \multirow[b]{2}{*}{$\begin{array}{l}\text { Total } \\
\text { No } \\
\text { tested }\end{array}$} & \multirow[b]{2}{*}{$\begin{array}{l}\text { Total No } \\
(\%)+\mathrm{Ve}\end{array}$} & \multirow[b]{2}{*}{$\begin{array}{l}\text { ND } \\
\text { only }\end{array}$} & \multicolumn{6}{|c|}{ Number (percentage) positive } \\
\hline & & & & $\begin{array}{l}\text { IBD } \\
\text { only }\end{array}$ & $\begin{array}{l}\text { FLU } \\
\text { A } \\
\text { only }\end{array}$ & $\begin{array}{l}\text { FLU } \\
\text { B } \\
\text { only }\end{array}$ & $\begin{array}{l}\text { EDS-76 } \\
\text { only }\end{array}$ & $\begin{array}{l}2 \\
\text { viruses } \\
\text { only }\end{array}$ & $\begin{array}{l}3 \\
\text { viruses }\end{array}$ \\
\hline $\mathrm{ECE}$ & 100 & $\begin{array}{l}82 \\
(82)\end{array}$ & $\begin{array}{l}21 \\
(21)\end{array}$ & $\begin{array}{l}31 \\
(31)\end{array}$ & $\begin{array}{l}7 \\
(7)\end{array}$ & - & $\begin{array}{l}2 \\
(92)\end{array}$ & $\begin{array}{l}18 \\
(18)\end{array}$ & $\begin{array}{l}3 \\
(3)\end{array}$ \\
\hline Chicks & 60 & $\begin{array}{l}56 \\
(93.7)\end{array}$ & $\begin{array}{l}2 \\
(3.7)\end{array}$ & $\begin{array}{l}9 \\
(15)\end{array}$ & $\begin{array}{l}7 \\
(11.7)\end{array}$ & * & $\begin{array}{l}8 \\
(13.7)\end{array}$ & $\begin{array}{l}20 \\
(33.7)\end{array}$ & $\begin{array}{l}10 \\
(16.7)\end{array}$ \\
\hline $\begin{array}{l}\text { Adults } \\
\text { Chicken }\end{array}$ & 140 & $\begin{array}{l}116 \\
(82.9)\end{array}$ & $\begin{array}{l}10 \\
(7.1)\end{array}$ & $\begin{array}{l}32 \\
(22.8)\end{array}$ & $\begin{array}{l}1 \\
(7.8)\end{array}$ & & $\begin{array}{l}6 \\
(4.3)\end{array}$ & $\begin{array}{l}42 \\
(30)\end{array}$ & $\begin{array}{l}15 \\
(1.7)\end{array}$ \\
\hline Total & 300 & $\begin{array}{l}254 \\
(84.7)\end{array}$ & $\begin{array}{l}33 \\
\text { (11) }\end{array}$ & $\begin{array}{l}72 \\
(24)\end{array}$ & $\begin{array}{l}25 \\
(8.3)\end{array}$ & - & $\begin{array}{l}16 \\
(53)\end{array}$ & $\begin{array}{l}80 \\
(26.7)\end{array}$ & $\begin{array}{l}28 \\
(9.3)\end{array}$ \\
\hline
\end{tabular}

Table 3 HI antibodies titres against selected viruses in village chickens of various age groups in Borno State, Nigeria

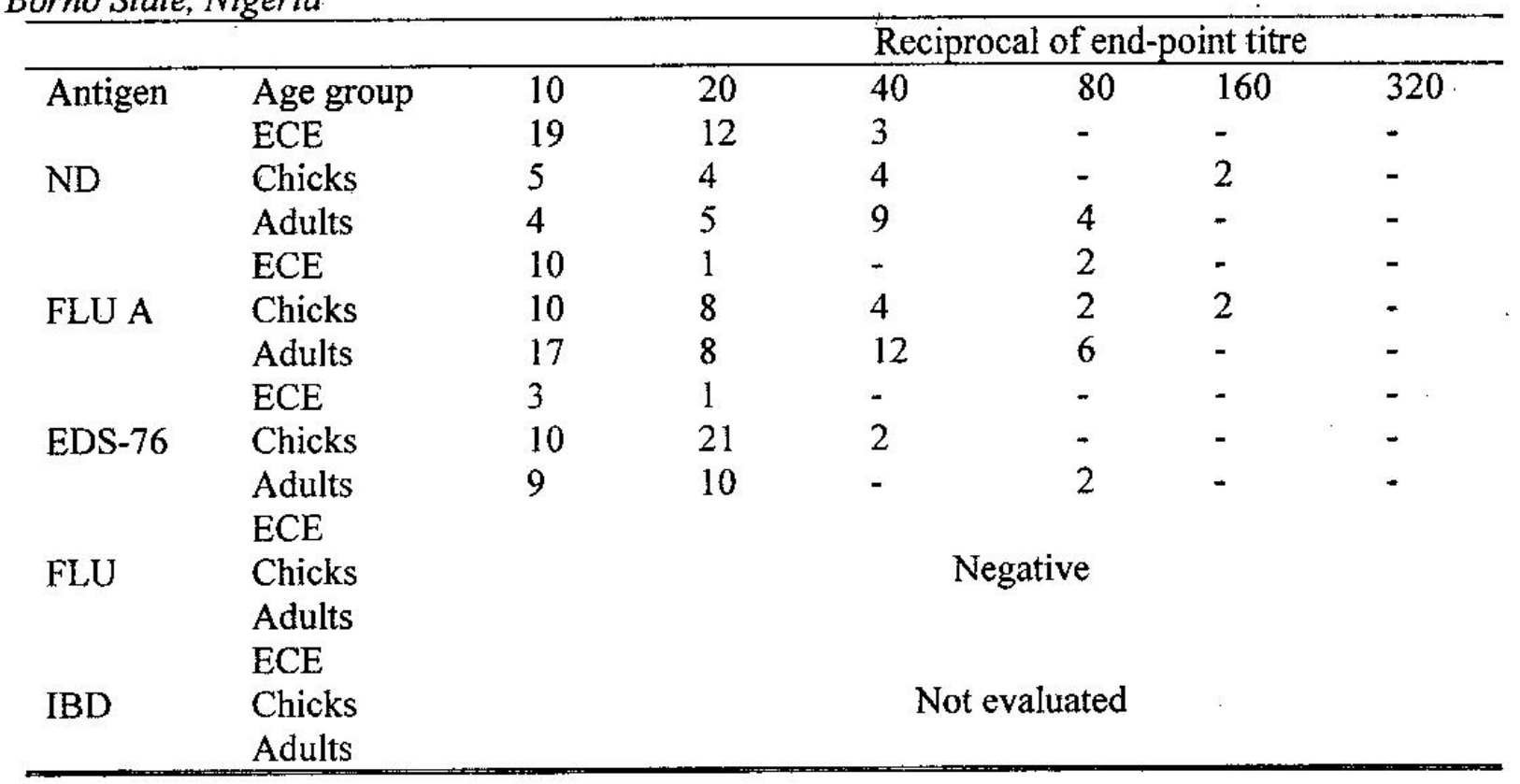




\section{Viral infections of village chickens}

\section{References}

Abdu, P. A., George, J. B. and Umoh, J. U. 1985. A study of poultry disease diagnosal at Zaria from 1981-1984. Nig. Vet. J. 14 (1): 63-65.

Abdu, P. A., Abdullahi, S.I., Adesiyan, A. A. and Ezeokoli, C. D. 1986. Infectious bursal disease WPSA Journal 42(3): 219-229.

Abdu, P. A.; Abdullahi S. U., Adesiyan, A. A. and Ezeokoli, C. D. 1987. Challenge study on infectious bursal disease in chicks derived from vaccinated hens. Trop. Anim. Hlth. Prod. 19: 47-52.

Adeniji, J. A., Adu, F. D., Baba, S. A., Ayoola, Owoade, A. A., and Tomori, $O$. 1993. Influenza $A$ and $B$ antibodies in pigs and chicken populations in Ibadan metropolis in Nigeria. Trop. Vet. 11: 39-45.

Allan, W. H. and Gough, R. F. A. 1974. A standard haemagglutination inhibition test for Newcastle disease: a macro and micro methods. Vet. Rec. 95: 120-123.

Aini, I., Ibrahim, A. L. Fauziah, O. and Hussein, A.A. 1987. Filed trials of Newcastle disease food pellet vaccine. In: Newcastle disease in Poultry. A new food pellet vaccine ACIAR monograph No. 5: 26-28.

Akoma, M. B. and Baba S. S. 1995. Survey for infectious bursal disease virus antibody in free-range and commercial bird in Bomo State, Nigeria. Studies and Res. In Vet. Med. 3: 46-48.

Ambali, A. G., Gashau. M. and Nawathe, D. R. 1991. Seralogical evidence of infectious bursal disease virus infection in grey breasted guinea fowl (namida melagris galeata palias) in an arid zone of Nig. J. Anim. Prod. 18: 88-90.
Baba, S. S., El-Yuguda, A. D. and Akom, M.M. 1998. Serological evidence of mixed infections with Newcastle disease and egg drop syndrome '76 viruses chickens in Borno State, Nigeria. Trop. Vet. (In Press).

Danvivatanaporn, J. 1987. Poultry production In: Newcastle disease in Poultry a new food pellet vaccine. ACIAR Monograph No. 5: 108-109.

Dipeolu, M. A., Kenipe, O. M. and Gbadamosi, A. J. 1998. Chick Mortality in indigenous chickens under free range system in Abeokuta, Nigeria. Nig. Vet. J. 19: 5-11.

Durojaiye, O. A., and Adene; D. F. 1988. Newcastle Disease and egg drop syndrome - 76 in guinea folws (Numidis Meleagris galesta pallas) J. Vet. Med. B. 35:L 152154.

Elssa, Y.M. 1985. Disease control problems in the middle east. World Poultry. Dec. 1985. pp. 33-37.

Hirai, R., Shimakura, S. and Hiros, M. 1972. Immunodiffusion reaction to infectious bursal disease virus. Avian Dis. 16: 61-64.

Ibrahim, A. L., Alinj, T. and Turiman, S. 1987. Technology transfer of Food pellet New-castle disease vaccine. In: New castle disease. A new food pellet vaccine. $A C L A R$ monograph No. 5: 35-36.

Jagne, J., Aini, I., Schat, A. A., Fennell, A, and Touray, O. 1991. Vaccination of village chickens in the Gambia against Newcastle disease using the heat resistant food pellet $\mathrm{V}_{4}$ vaccine. Avian Path. 20: 271-274. 


\section{Yuguda and Baba}

Jong, J. C., Umoh, J. U., Abdu, P. A. and Saidu, L., 1992. Retrospective studies of Cumboro disease seen in Ahmadu Bello Univeristy, Zaria Veterinary teaching hospital. In: Book of proceddings of the Scientific session of Nig. Vet. Med. Assoc. Kaduna 1992. pp. 117-122.

Lamorde, A. G., 1996. The role of veterinarian in a developing economy Nig. Vet. J. 1 (1): 106-111.

Nawathe, D. R. and Abegunde, A. 1980. Egg drop syndrome-76 in Nigeria serological evidence in commercial farms. Vet. Rec. 107: 466- 467 .

Okoye, J.O. A., Orajaka, I.J. E., and Nwosuh, C. J., 1992. Antibody response of local and exotic Nigerian Chickens to infectious bursal disease virus. In: Book of proceeding of the scientific session of Nig. Vet. Med. Assoc. Kaduna, 1992. pp. 56-58.

Pejkovski, C., Devela'ar, F. G and Kouwenhoven, B. 1970 . Immunosuppressive effects of infectious bursal disease virus on vaccination against infectious bronchitis Avian Path. 8: 95-106.

Spradbrows, P. N. 1987. Newcastle disease on overview. In: Newcastle disease a new food pellet vaccine. ACIAR monograph NO. 5: 12-18.

WHO, 1988. Influenza virus reagents for haemagglutination inhibition test. Centre for disease control, collaborating center for influenza Atlanta Georgia.

(Received 29 April 1998; Accepted 15 May 2001) 